\title{
Assessing the impact of sea-level rise on a vulnerable coastal community in Accra, Ghana
}

\begin{tabular}{|c|c|}
\hline \multicolumn{2}{|c|}{$\begin{array}{l}\text { Authors: } \\
\text { Kwasi Appeaning Addo }{ }^{1} \\
\text { Michael Adeyemi }{ }^{1}\end{array}$} \\
\hline \multicolumn{2}{|c|}{$\begin{array}{l}\text { Affiliations: } \\
{ }^{1} \text { Department of Marine and } \\
\text { Fisheries Sciences, University } \\
\text { of Ghana, Ghana }\end{array}$} \\
\hline \multicolumn{2}{|c|}{$\begin{array}{l}\text { Correspondence to: } \\
\text { Kwasi Appeaning Addo }\end{array}$} \\
\hline \multicolumn{2}{|c|}{$\begin{array}{l}\text { Email: } \\
\text { kappeaning-addo@ug.edu.gh }\end{array}$} \\
\hline \multicolumn{2}{|c|}{$\begin{array}{l}\text { Postal address: } \\
\text { PO Box LG 99, University of } \\
\text { Ghana, Ghana }\end{array}$} \\
\hline \multicolumn{2}{|c|}{$\begin{array}{l}\text { Dates: } \\
\text { Received: } 07 \text { Aug. } 2012 \\
\text { Accepted: } 25 \text { Apr. } 2013 \\
\text { Published: } 15 \text { Aug. } 2013\end{array}$} \\
\hline \multicolumn{2}{|c|}{$\begin{array}{l}\text { Keywords: } \\
\text { Disasters; experiences; } \\
\text { interpreting; perceptions } \\
\text { script; risk }\end{array}$} \\
\hline \multicolumn{2}{|c|}{$\begin{array}{l}\text { How to cite this article: } \\
\text { Appeaning Addo, K. } \\
\text { \& Adeyemi, M., 2013, } \\
\text { 'Assessing the impact of } \\
\text { sea-level rise on a vulnerable } \\
\text { coastal community in Accra, } \\
\text { Ghana', Jàmbá: Journal of } \\
\text { Disaster Risk Studies 5(1), } \\
\text { Art. \#60, } 8 \text { pages. } \\
\text { http://dx.doi.org/10.4102/ } \\
\text { jamba.v5i1.60 }\end{array}$} \\
\hline \multicolumn{2}{|c|}{$\begin{array}{l}\text { Copyright: } \\
\text { (C) 2013. The Authors. } \\
\text { Licensee: AOSIS } \\
\text { OpenJournals. This wC } \\
\text { is licensed under the } \\
\text { Creative Commons } \\
\text { Attribution License. }\end{array}$} \\
\hline \multicolumn{2}{|l|}{ Read online: } \\
\hline 四的回 & $\begin{array}{l}\text { Scan this QR } \\
\text { code with your } \\
\text { smart phone or } \\
\text { mobile device } \\
\text { to read online. }\end{array}$ \\
\hline
\end{tabular}

Climate change and its associated sea-level rise are expected to significantly affect vulnerable coastal communities. Although the extent of the impact will be localised, its assessment will adopt a monitoring approach that applies globally. The topography of the beach, the type of geological material and the level of human intervention will determine the extent of the area to be flooded and the rate at which the shoreline will move inland. Gleefe, a coastal community in Ghana, has experienced frequent flooding in recent times due to the increasing occurrence of storm surge and sea-level rise. This study used available geospatial data and field measurements to determine how the beach topography has contributed to the incidence of flooding at Gleefe. The topography is generally low-lying. Sections of the beach have elevations of around $1 \mathrm{~m}$, which allows seawater to move inland during very high tide. Accelerated sea-level rise as predicted by the Intergovernmental Panel on Climate Change (IPCC) will destroy homes of the inhabitants and inundate the Densu wetlands behind the beach. Destruction of infrastructure will render the inhabitants homeless, whilst flooding of the wetlands will destroy the habitats of migratory birds and some endangered wildlife species such as marine turtle. Effective adaptation measures should be adopted to protect this very important coastal environment, the ecology of the wetlands and the livelihoods of the community dwellers.

\section{Introduction}

Sea-level rise as a result of climate change (Rahmstorf et al. 2007) has become a serious challenge to sustainable management of the coastal zone globally. The global average sea level rose at an average rate of around $1.8 \mathrm{~mm}$ per year from 1961 to 2003 and at an average rate of about $3.1 \mathrm{~mm}$ per year from 1993 to 2003 (Intergovernmental Panel on Climate Change [IPCC] 2007). Much of the rise in sea level has been due to the rise in global temperature associated with climate change. The trend is expected to continue for centuries (Nicholls et al. 2007) and has the potential to further increase the threats of flooding in coastal cities (Kebede et al. 2012). Its impact on beach morphology will be influenced by the prevailing topography (Strauss et al. 2012).

Accelerated sea-level rise results in a spatial shift of coastal geomorphology, which is manifested through the redistribution of coastal landforms (Crooks 2004). Increasing water depth at the shore, due to sea-level rise, results in enhanced wave and tidal activities through energy dissipation along the coast. Coastal landforms responds to this hydrodynamics by migrating both normal and parallel to the shore in order to maintain their position within the energy gradient and also attempt to restore their equilibrium state.

Threats from sea-level rise and the resultant increased erosion and flooding require planned adaptation strategies to preserve the coastal environment and protect coastal investments. This is because the coastal zone is a hub of social and economic activities, and accommodates over $50 \%$ of the global population (Woodroffe 2003). It is estimated that about $40 \%$ of the West African population live in coastal cities and this is expected to increase to about 50 million inhabitants by 2020 (Boko et al. 2007). Hence coastal erosion-related disasters in coastal communities will affect the economy of coastal nations significantly and affect coastal ecosystems. They will also interfere with the water supply for human consumption and agricultural purposes due to salt water intrusion into coastal aquifers. The most vulnerable areas within the coastal zone are the low-lying coastal communities, coastal defense structures and coastal infrastructures.

Coastal communities will react differently to sea-level rise, depending on the prevailing local geomorphic and geological conditions as well as the effectiveness of erosion-driving forces such as waves and tides. It is estimated that over 700000 people will be displaced in Nigeria, with about $0.2 \mathrm{~m}$ rise in sea level, whilst a sea-level rise of about $0.4 \mathrm{~m}$ in the Bay of Bengal would put approximately $11 \%$ of the Bangladesh's coastal land underwater and create about 
7-10 million climate refugees (Peehler 2007; Wax 2007). According to Hinkel et al. (2011), by 2100, 16-27 million people are expected to be flooded per year, and annual damage costs range between $\$ 5$ and $\$ 9$ billion, if no adaptation takes place. A study by Dasgupta et al. (2007) revealed that hundreds of millions of people in the developing world are likely to be displaced by sea-level rise within this century, and accompanying economic and ecological damage will be severe for many. Climate change projections have identified the West African coastal zone to be at risk of flooding by 2080 (Nicholls \& Tol 2006). The West African coast is considered highly vulnerable to climate change and its associated sea-level rise due to the concentration of poor population in potentially hazardous areas that are at risk to such changes (Boko et al. 2007).

The urgent need for awareness of the quality of global coastal ecosystems being adversely impacted by sea-level rise and the threat of sea-level rise-induced coastal erosion on coastal investments has accelerated efforts to assess, monitor and mitigate their impact. Analysis of the migrating pattern of the shoreline over time and the changes in the topography of the beach-face enables the impact of sea-level rise on beaches to be assessed. This study used available geospatial data and field measurements to determine how the beach topography has contributed to the incidence of flooding at Gleefe, a coastal community in Accra, Ghana.

\section{The study area}

Gleefe has in recent times been experiencing beach erosion problems which threaten life and property (Campbell 2006; De-Graft 2011). The study area, which is part of Accra, the capital city of Ghana, is located at $5.3180^{\circ} \mathrm{N}$ and $0.1001^{\circ} \mathrm{W}$ along the Gulf of Guinea. It falls within the western coastal geomorphic section of Accra (Appeaning Addo, Walkden \& Mills 2008). The study area has been the subject of recent studies due to the high incidence of coastal erosion and flooding (Amoani, Appeaning Addo \& Laryea 2012; Appeaning Addo et al. 2011; De-Graft 2011; Oteng-Ababio,

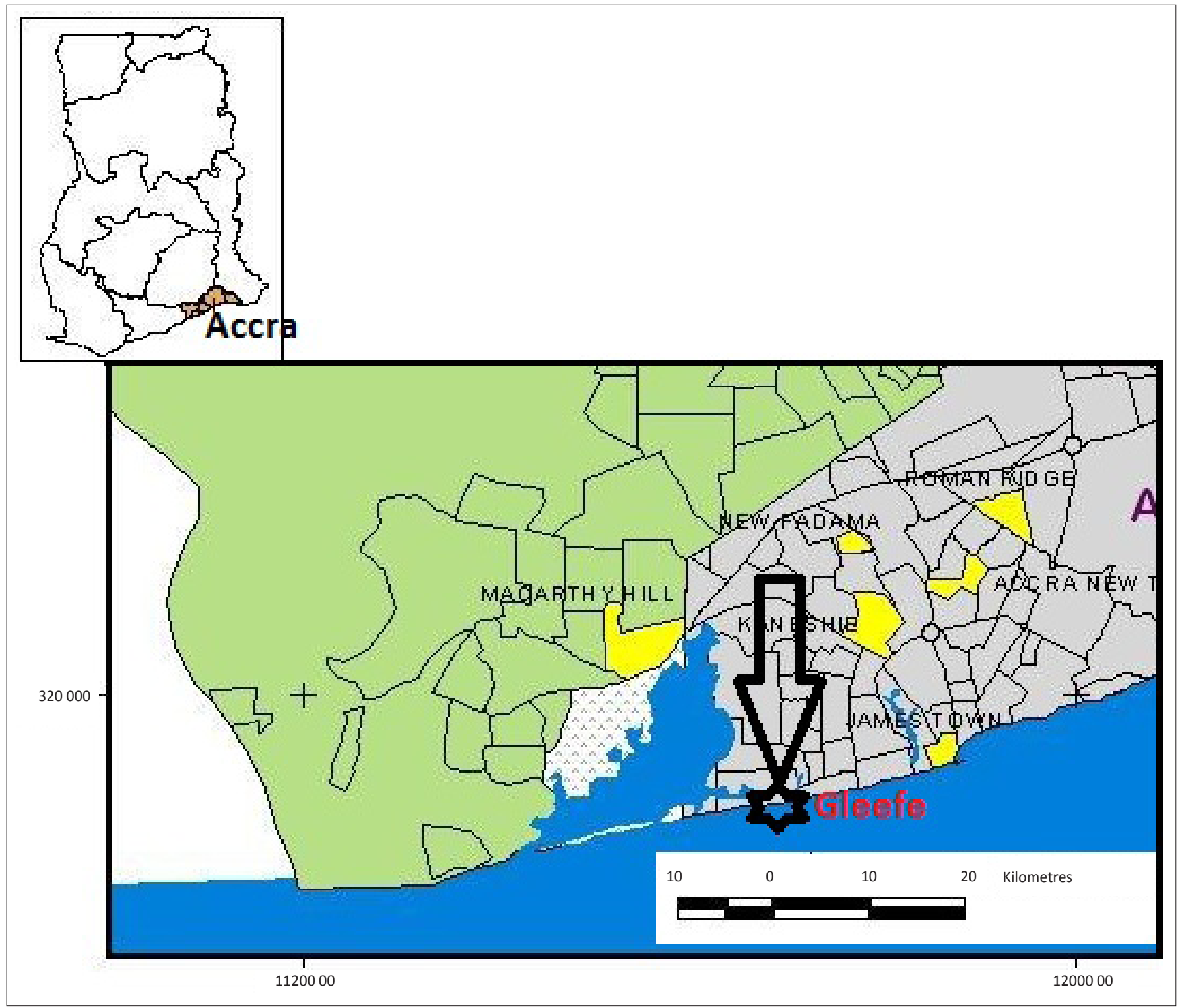

Source: Ghana Survey Department, n.d., Map of Ghana, Map sales division of Ghana Survey Department, Accra

FIGURE 1: The study area showing its location in Ghana. 
Owusu \& Appeaning Addo 2011). The community is bounded on the north by the Sakumo Lagoon and on the south by the Gulf of Guinea (Figure 1). It is located on the barrier ridge separating the Sakumo Lagoon from the sea, and the geology consists of poorly consolidated rocks (Muff \& Efa 2006). The study area experiences significant differences in the amount and seasonal distribution of precipitation. It has two rainy seasons, with the major season between April and July, and the minor one between September and November. Sediment transport to the littoral zone is high during the rainy seasons as the rivers discharge their sediment from the upland catchment areas into the sea. Inversely, sediment transport reduces during the dry season, when temperatures are over $30^{\circ} \mathrm{C}$, resulting in the drying up of most of the rivers.

Gleefe, similar to most parts of Accra coast, has a relatively open coast that enables considerably strong, unimpeded swell waves to reach the shore (Appeaning Addo 2009). The swell waves break obliquely, generating longshore currents (Ly 1980). The significant wave height for $50 \%$ of the time is about $1.4 \mathrm{~m}$, the period is between $10 \mathrm{~s}$ and $15 \mathrm{~s}$, whilst spring high tide is about $1.26 \mathrm{~m}$ (AESC 1980). Figure 2 shows graphs of the dominant wave direction, mean period and surge as well the mean wind climates. Three types of current operate along the coast in the west-east direction. They include the longshore current, which varies between $0.5 \mathrm{~m} / \mathrm{s}$ and $1.5 \mathrm{~m} / \mathrm{s}$, the Guinea current, which can measure up to $0.5 \mathrm{~m} / \mathrm{s}$ during the rainy season but is weak most of the year, and the tidal current, which plays no significant role in the coastal morphology (Wellens-Mensah et al. 2002). The wavegenerated, relatively high, longshore current is responsible for transporting sediment in the littoral zone (AESC 1980). The study area is low-lying and hence has stagnant water pools in many parts. The population of Gleefe consists mostly of fishermen and fishing is the main economic activity in the community and thus the main source of livelihood for the entire community (Amoani et al. 2012). Whilst the men are engaged in 'corporate fishing', the women work as fishmongers and provide other retail supporting services (selling of drinks, food, etc.). Most of the children provide fishing assistance to their parents, including the mending of torn nets.

Gleefe and its environs experience relatively severe erosion (Amoani et al. 2012; De-Graft 2011; Oteng-Ababio et al. 2011). The area is considered to be extremely vulnerable (Anokwa, Martin \& Muff 2005; Appeaning Addo et al. 2008; Appeaning Addo et al. 2011), due to the presence of unconsolidated as well as poorly consolidated sediment. The beach is made up of a long sand bar, traversing about $2 \mathrm{~km}$ of the coast, behind which is a lagoon. Morphological differences along the beach are absent as the sand bar is only partially divided into an eastern and western section by the Pambros salt production area (Amoani et al. 2012). The salt production site is protected by boulders and thus appears as a riprap. Although erosion is evident on the entire beach, its signature is mostly seen on the eastern section where the width of the sand bar is greatly reduced and settlements suffer the consequences of erosion (Figure 3). Although the western section also experiences erosion, it has a wider sand bar that reduces its impact. Behind the sandbar on this section of the beach is a stretch of
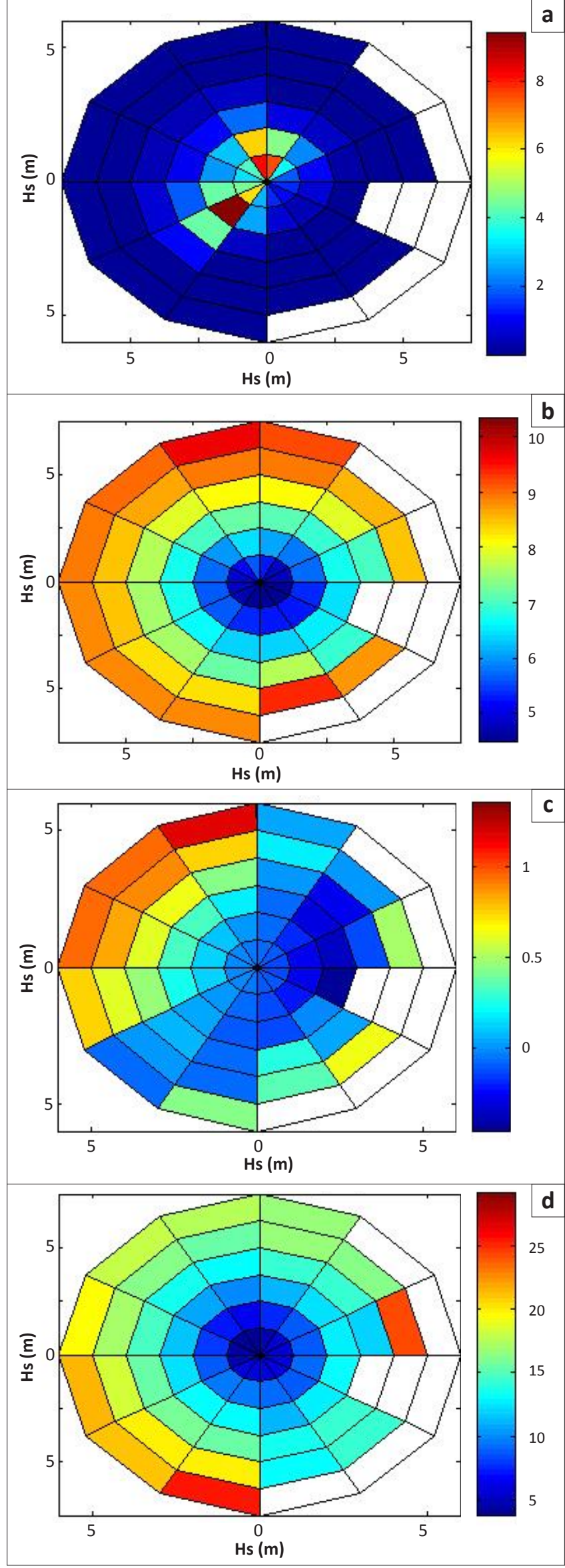

FIGURE 2: Wave rose along Ghana coast: (a) percentage occurrence, (b) meanT (c) mean surge and (d) mean wind speed. 
mangrove species. Observations indicate that the inhabitants of Gleefe and the surrounding areas depend on the beach in many ways. Some of them use it as landing sites and canoe docks.

The study area presently experiences severe flooding due to an upsurge in storm surge activities and tidal waves (DeGraft 2011), which can be attributed to a relative sea-level rise as a result of climate change. A significant percentage of the population has lost property due to increased flood erosion (Campbell 2006). Increased erosion in recent times continues to threaten recreational activities, industries and a major Ramsar wetland site - Densu (Appeaning Addo et al. 2008). The Densu wetland is a habitat for sensitive endemic species and serves as a fly zone for migratory birds (Ahulu, Nunoo \& Awusu 2006). A major large-scale salt production company, Pambros, is located within the wetland.

The sea level in Ghana is rising at a rate of about 2 mm/yr (Appeaning Addo 2009; Ibe \& Quelennec 1989), which is in conformity with the global estimate (Armah et al. 2005). Relative sea-level rise is confirmed by filtered tide measurements from the Takoradi Tide Gauge Station and analysed by the Intergovernmental Panel on Climate Change (IPCC 1995) (Figure 4). A recent study by Muff and Efa (2006), through mapping of unconsolidated sediments of marine, lagoon and fluvial sand of all lagoons in Accra showed evidence of a high water stand of relatively short duration in recent times. The study concluded that a coastline below the present sea level existed before the sand bodies were deposited in the lagoons and estuaries. Analysis of sediment cores corroborate observations by Muff and Efa (2006) that a coastline once existed between $12 \mathrm{~m}$ and $18 \mathrm{~m}$ below the present sea level in Accra (Geoconsultants 2005). These findings again confirm studies by the Soil Research Institute of Ghana (SRI 1966) that identified historic changes in the sea level in the Accra coast. Changes in the sea level have been a major contributing factor in the shoreline evolution on Ghana's coast. It has caused shoreline erosion of the soft cliff areas, erosion of the laterite soils on top of hard rocks, thus exposing the substratum, and inundation of the lowlands over many years.

\section{Methodology}

The beach face was mapped using the Real-Time Kinematic (RTK) GPS method. An important advantage of this method over traditional beach surveying methods is the greater spatial coverage that can be achieved along the beach. This is accomplished by running transect survey lines along the beach face. A reconnaissance survey was conducted in the study area to identify a suitable location for establishing a control point that served as the reference point. The selected control point was on relatively high ground that facilitated good communication between the base receiver and the rover receiver. A static survey was conducted to coordinate the control point that enabled it to be used as the base station for the beach-face survey. One receiver was stationed permanently over the established reference station during the period of the data capture, whilst a rover was moved over the beach face at a defined transect interval. The process

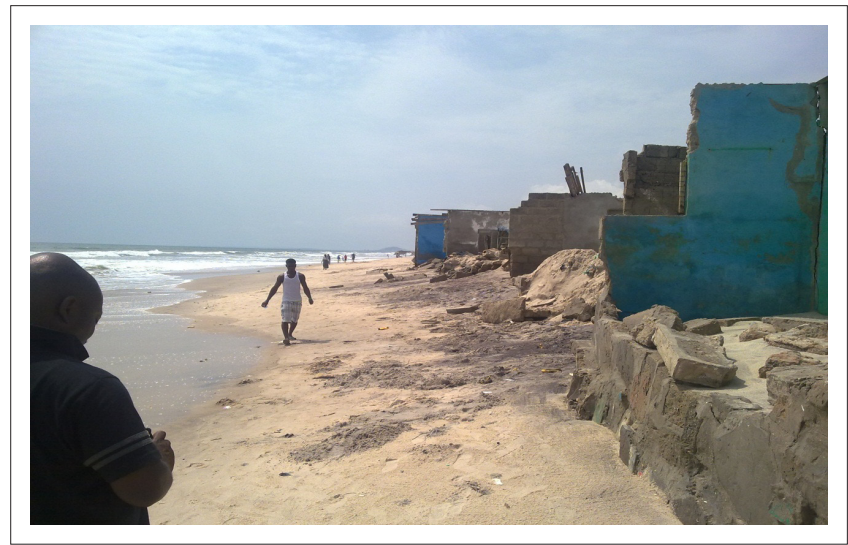

Source: Picture taken by Kwasi Appeaning Addo

FIGURE 3: Collapsing buildings along the beach at Gleefe.

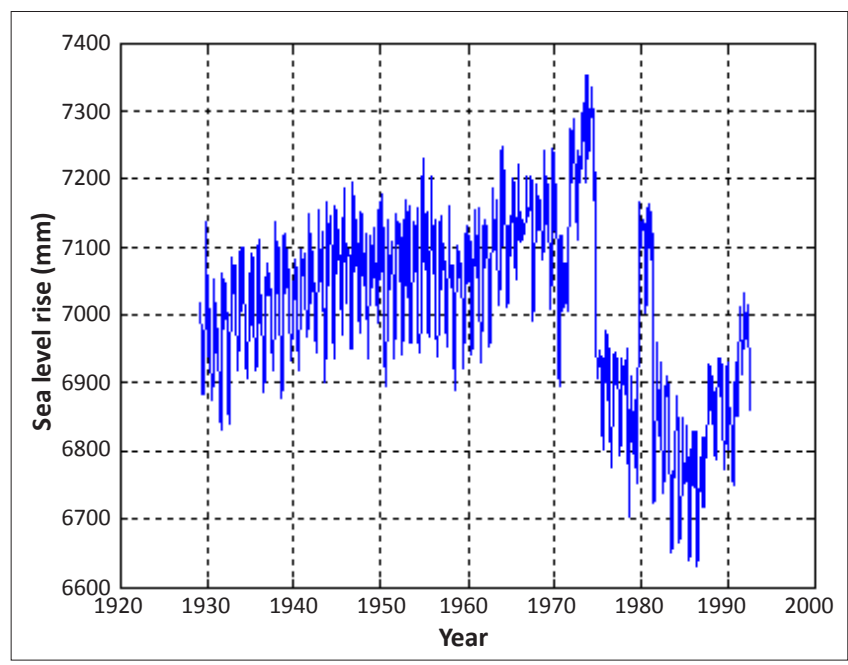

Source: PSMSL, 2002, Obtaining sea level data, viewed 18 June 2012, from http://www.pol. ac.uk/psmsl/datainfo/

FIGURE 4: Plot of measured values of sea level data from 1929-1992.

enabled transmission of real-time corrections from the base receiver to the rover receiver during the mapping process. The reference station established was connected to the Ghana national grid system. This will facilitate future monitoring activities as well as ensure compatibility with historic maps to enable change detection. The rover receiver was mounted on a monocycle to facilitate easy movement. Geographic coordinates (latitude and longitude) and elevations of the defined transect lines over the beach face were recorded. Postprocessing of the data used the Spectrum Survey software. The captured points were processed at the horizontal and vertical network accuracy of $0.010 \mathrm{~m}$ and $0.020 \mathrm{~m}$ respectively, at a $95 \%$ confidence level. The beach-face spot heights data enabled digital elevation models (DEM) to be generated. The DEM and the profiles generated revealed the topographical perspective view of the beach, showing the shape and the relative elevation of the beach face.

Near vertical aerial photographs captured in 1996 and an orthophoto map developed in 2005 were obtained from the Survey and Mapping Division of the Ghana Lands Commission. The high-water marks were digitised on screen to represent the shoreline positions for the two epochs. The 1996 photos were georeferenced using a 1974 digital 
topographic map of Ghana that was also obtained from the Survey and Mapping Division. The reliability of the 1974 map has been assessed by Appeaning Addo et al. (2008), which increased confidence in using it as the reference. The 2005 orthophoto was already georeferenced. Overlay of the two different date shoreline positions enabled changes to be detected and rates of change to be estimated.

The Digital Shoreline Analysis System (DSAS) software was used to compute the historic rates of change in the shoreline positions. The software generates orthogonal transects at a user-defined interval that cross the shoreline positions. It automatically computes the shoreline rates of change statistics at the points where the shoreline and the orthogonal transect intersect. The software also allows the reliability of the estimated rates of change results to be established. Several methods are used to estimate the rates and included the endpoint rate, jacknife, linear regression, average of rates and weighted linear regression. Adoption of a particular method is influenced by the number of shoreline positions available and the accuracy required. A transect interval of $100 \mathrm{~m}$ was selected for this study. This is considered appropriate since according to Appeaning Addo (2009), spacing below $100 \mathrm{~m}$ does not result in improved estimates of shoreline change rates.

The end point rate (EPR) method was used for this study since only two shoreline positions were available. EPR calculates the rate of change by dividing the distance of shoreline movement by the time elapsed between the earliest and the latest measurement. It is estimated that over twothirds of agencies that use shoreline rates of change data to manage coasts apply the EPR method (Fenster \& Dolan 1994), whilst Crowell, Leatherman and Douglas (2005) consider it as the most commonly used method to compute shoreline rates of change. Average trends and short-term variations in shoreline change were calculated for the nine-year period.

\section{Results}

The elevation model of the beach shows its topography (Figure 5). The topography rises more to the west relative to the east. The highest point is about $4 \mathrm{~m}$ high.

Contours generated from the beach-face surveyed data revealed the relative differences in elevation along the beach (Figure 6). This is relevant as it shows the low areas that allow seawater to move inland during very high tide and storm surge.

A cross-sectional profile was drawn through the highest section (Figure 7). Behind this point is part of the Densu wetlands where the commercial salt production company Pambrose is located.

Cross-sectional profiles of the eastern and central sides of the beach (Figures 8 and 9) reveal a relatively low elevation beach with elevation between $1.5 \mathrm{~m}$ and $2 \mathrm{~m}$. The beach also experiences over-wash due to wave action.

The longitudinal profile (Figure 10) generated along the beach revealed areas with relatively low elevations on the beach. These areas are suspected to act as channels that enable the seawater to move further inland during very high tides as reported by De-Graft (2011).

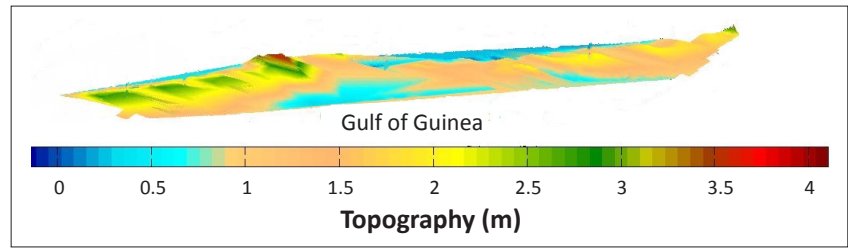

FIGURE 5: Model of the beach face.

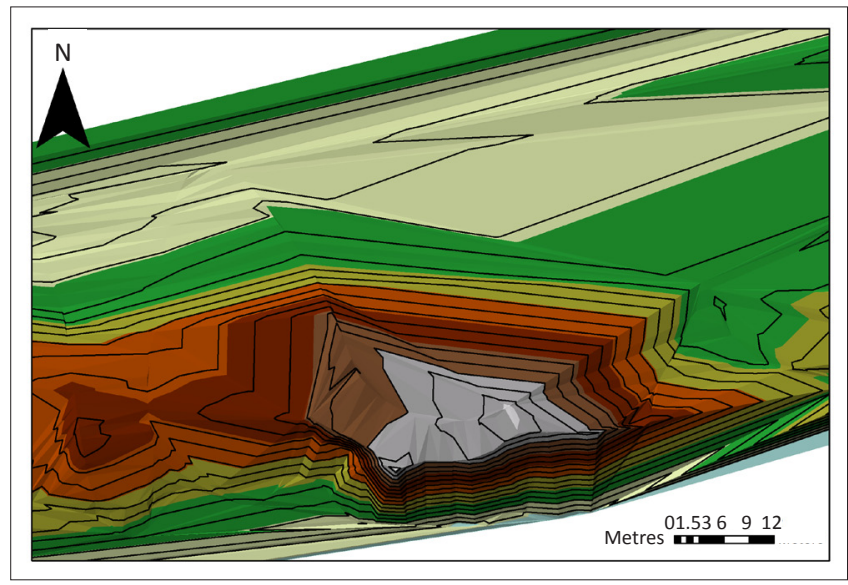

FIGURE 6: Contour on part of the beach at $0.2 \mathrm{~m}$ contour intervals.

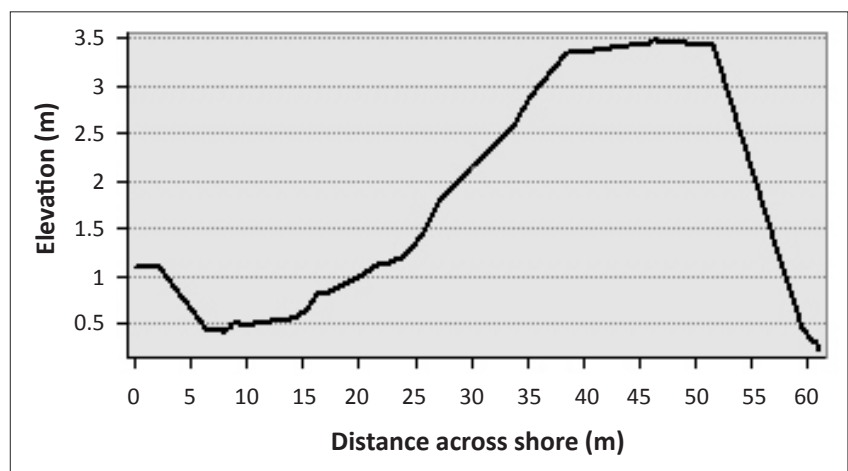

FIGURE 7: Cross-sectional profile of the highest point.

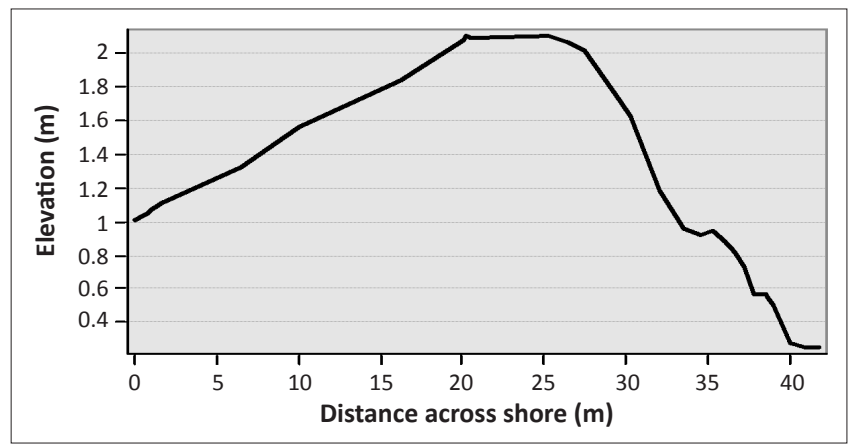

FIGURE 8: Cross-shore profile on part of the eastern beach.

Merging the two digitised shoreline positions enabled changes over the nine-year period to be detected (Figure 11). Although the observed change could be part of a cyclic event that may recover after some time, it confirms previous studies that identified the area to be eroding in the long term (Amoani et al. 2012; Appeaning Addo et al. 2011).

The estimated average shoreline rates of change, computed at the intersection of the orthogonal transect and the shoreline 


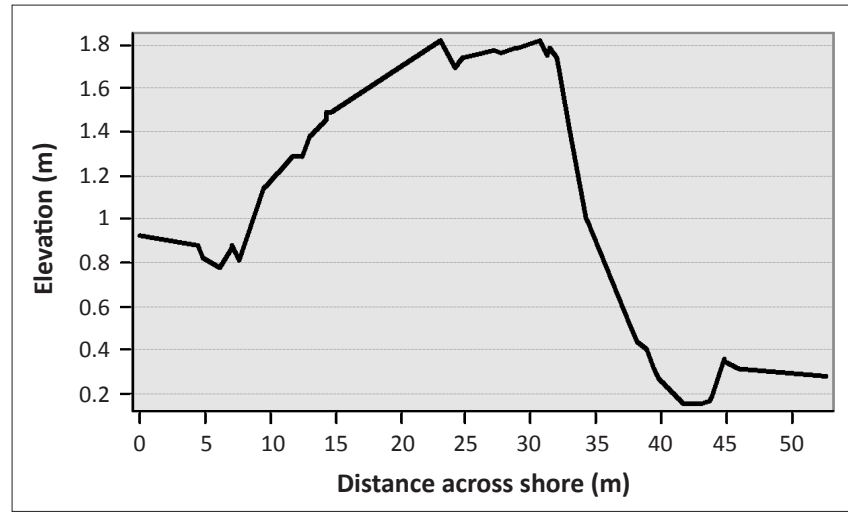

FIGURE 9: Cross-shore profile on part of the central beach.

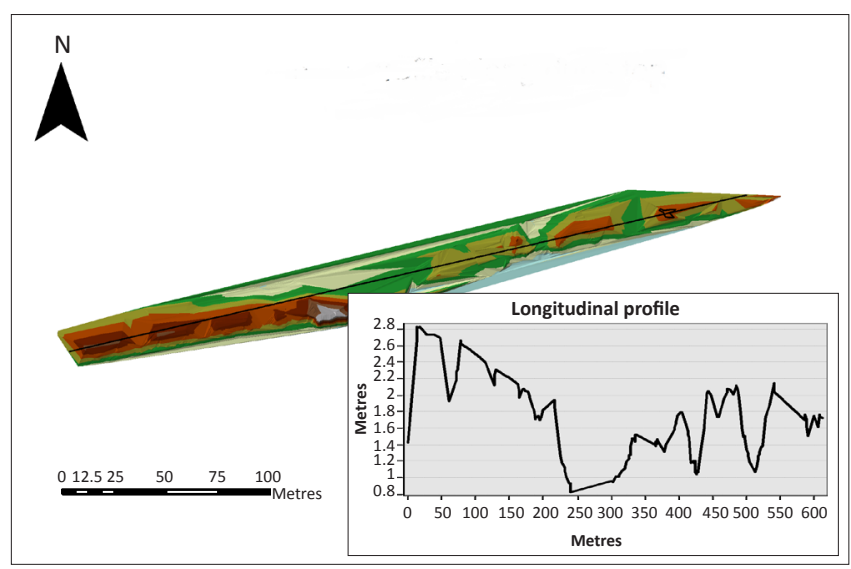

FIGURE 10: Longitudinal profile along the beach.

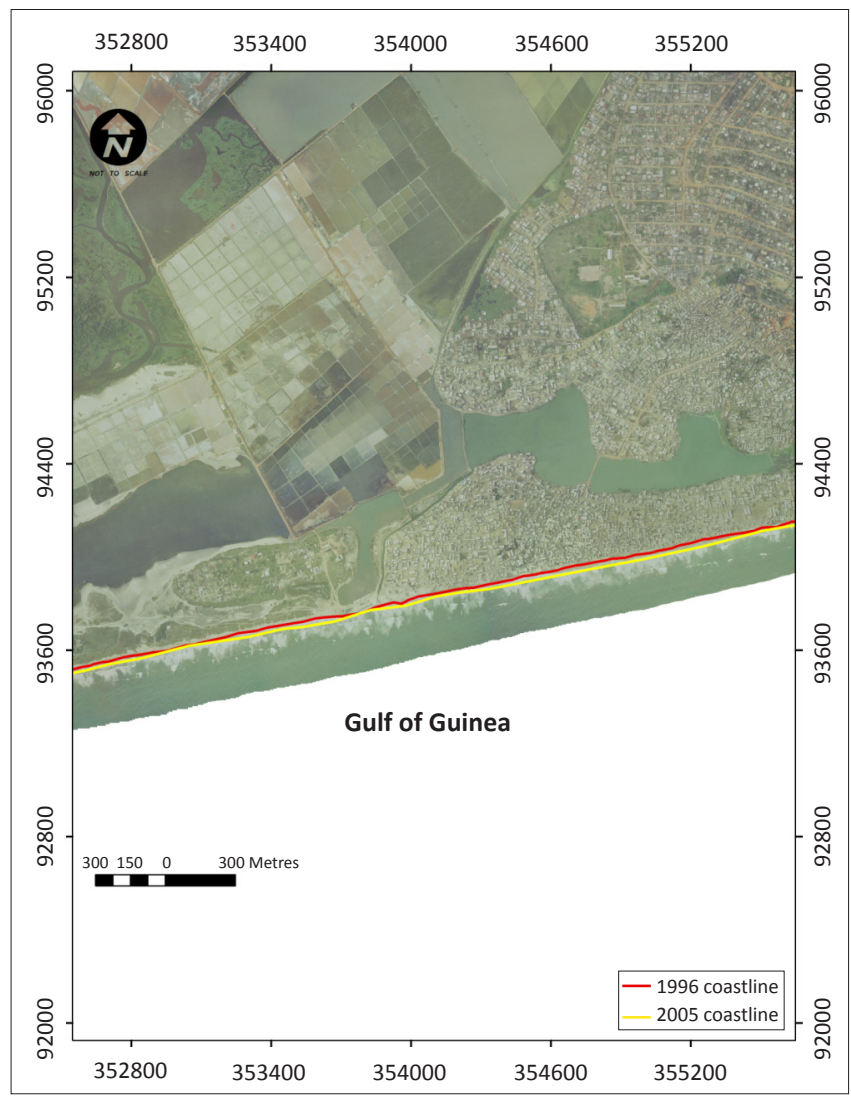

FIGURE 11: Overlay of the two shoreline positions to detect change.

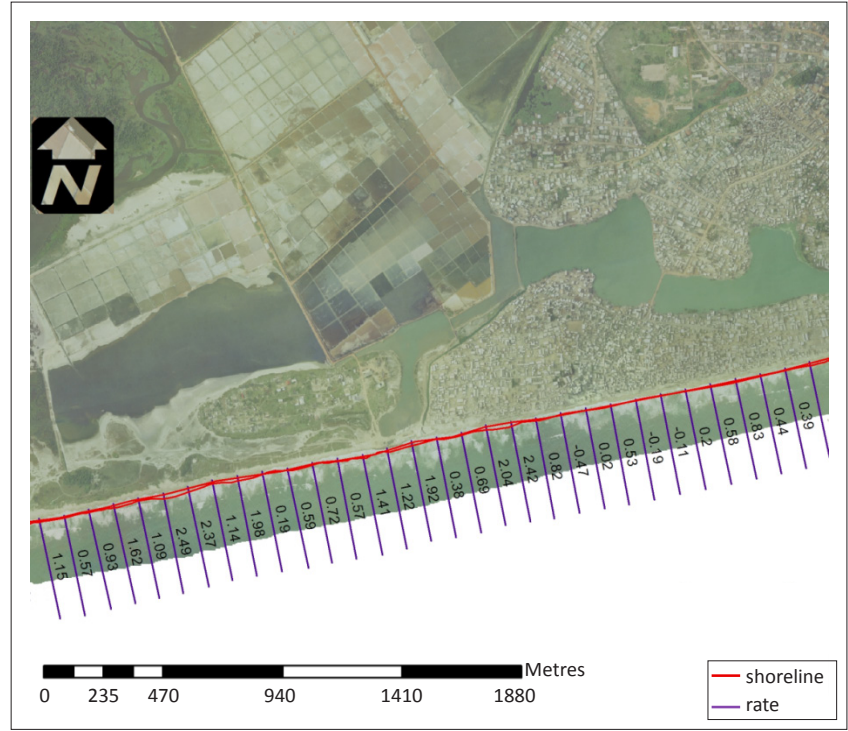

FIGURE 12: Mapped shoreline position along the Gleefe coast.

positions (Figure 12) is about $1.4 \mathrm{~m} / \mathrm{yr}$. This is slightly higher than the short-term rate estimated for 2005 and 2011 by Amoani et al. (2012) and the long-term rate estimated by Appeaning Addo et al. (2008).

\section{Discussion}

Various reasons have been assigned for the incidence of increased erosion at Gleefe by previous studies (Amoani et al. 2012; Oteng-Ababio et al. 2011). The study by Appeaning Addo (2009) identified climate change and its associated sea-level rise as a major cause. Increases in temperature as reported by the EPA (2003) have resulted in increased sea level due to thermal expansion. This situation enables waves to break closer to the beach, dissipating their energy and transporting dislodged sediment along and across the shore. It has also been established that beach sand mining for construction purposes is a major source of coastal erosion in Ghana (Mensah 1997). Mining of the beach sand has resulted in a situation of imbalance in the sediment budget and has led to instability in the system. The beach sand is thus eroded to compensate for the deficit created as the system strives to achieve equilibrium. Although beach sand mining is banned (Appeaning Addo et al. 2008), the practice is on-going due to lack of employment for the inhabitants. This action has thus exacerbated the natural migration pattern of the shoreline in the study area. This partly explains the observed relatively high erosion in the study area. Climate change has also increased the incidence of storm surge, which results in flooding during very high tides. The relatively high longshore current as reported by the AESC (1980) and unplanned infrastructure development (World Bank 1995) have also contributed considerably to the observed incidence of erosion in the study area.

The elevation model developed for the beach (Figure 5) shows uneven beach-face elevation. The western part is relatively higher than the central and eastern parts. The intertidal zone has a relatively low gradient and the slope of the beach is 
about $1 \mathrm{~m}$ (Amoani et al. 2012). The longitudinal profile (Figure 10) reveals that portions of the beach have elevations below $1 \mathrm{~m}$. The portions with very low elevations can be explained by the persistent removal of beach sand from such areas for construction. These areas serve as channels for the seawater to flood the coastal community during very high tides.

Sudden changes in wind intensity result in a storm surge that pushes the seawater inland and results in flooding. Wind speed has increased significantly due to climate change (ScienceDaily 2008). This phenomenon explains in part the periodic flooding in the study area. The geology of the study area is made up of unconsolidated sediment (Anokwa et al. 2005). The soft rocks are unable to withstand the energy of the waves due to their low strength. The relatively high longshore currents generated by the breaking waves erode and transport the sediment (AESC 1980). This explains in part the considerably high rate of erosion along the Gleefe beach (Figure 3). The elevation to the east of the study area is about $4 \mathrm{~m}$ and the commercial salt mining company has dumped boulders along this section of the beach to control erosion and prevent flooding of the salt pans behind the beach. This explains the relatively low short-term shoreline change along this portion of the beach, as indicated by Amoani et al. (2012) and confirmed by this study.

Presently, the sea level is rising at a historic rate of between $2 \mathrm{~mm} / \mathrm{yr}$ and $3 \mathrm{~mm} / \mathrm{yr}$ (Sagoe-Addy \& Appeaning Addo 2012). Sea-level rise is predicted to affect the study area due to the relatively low elevation of the beach (Appeaning Addo et al. 2011). A rise in sea level by about $1 \mathrm{~m}$ will significantly affect the central and the eastern portions of the study area (Figure 10). The study area experiences overwash, in which the beach sediment is moved backwards. However, the relatively low elevations behind the beach, as indicated by the cross sectional profiles (Figures 7, 8 and 9), will result in a spreading out of the sediment and facilitate flooding. This will inundate the Densu wetlands and destroy the saltpans. The wetland has been identified as a highly productive and an important habitat for marine and migratory birds (BirdLife International 2012). Destruction of this ecological site, which is the second most important site for the rare Dougallii tern, will endanger the habitats of migratory birds and affect approximately 35000 waterfowl (Birdlife International 2012). Flooding of the saltpans will further swell the unemployment problem that prevails in the area. The situation will reduce tax revenue from the salt industry and destroy the emerging bird-watching tourism industry. Three species of marine turtle, Lepidochelys olivacea, Chelonia mydas and Dermochelys coriacea, that have been recorded nesting on parts of the beach (Birdlife International 2012) will also have their nesting grounds destroyed.

\section{Conclusion}

Various factors combined have contributed to the observed erosion at Gleefe. However, sea-level rise and increased storm surge activities as a result of climate change have exacerbated the incidence of flooding in recent times. Mining of beach sand has resulted in the development of channels along the beach that allow seawater to move further inland during very high tide and has also reduced the volume of the beach sand significantly. It is estimated that the beach volume is less than $10 \mathrm{~m}^{3} / \mathrm{m}$ length (Appeaning Addo et al. 2008; Walkden \& Hall 2005), which is expected to have little influence on reducing erosion. According to Dickson, Walkden and Hall (2007), beach sand volumes below approximately $10 \mathrm{~m}^{3} / \mathrm{m}$ length were independent of beach volume change, whilst larger volumes reduced erosion rates. Future sea-level rise as predicted by the IPCC (2007) will inundate a large portion of Gleefe and destroy the ecology of the Densu wetlands. Sources of livelihood of the coastal dwellers will be destroyed and this will result in economic and social challenges. Although Oteng-Ababio et al. (2011) have suggested relocation as an adaptation option for communities within the western part of Accra to mitigate the impact of climate change and sealevel rise, other options such as constructing sea walls and revetments should be explored.

\section{Acknowledgements Competing interests}

The authors declare that they have no financial or personal relationship(s) that may have inappropriately influenced them in writing this article.

\section{Authors' contributions}

K.A.A. (University of Ghana) initiated the project, supervised it, contributed to the data analysis and writing of the manuscript. M.A. (Univerity of Ghana) did the data collection, contributed in analysing the data and writing of the manuscript.

\section{References}

AESC, 1980, Architectural and Engineering Services Corporation, Environmental Protection Agency report, Hydrology Division: Coastal Erosion and Proposed Protection Works at Keta, Accra, Ghana.

Ahulu, M.A., Nunoo, F.K.E. \& Owusu, E.H., 2006, 'Food preferences of the common tern, Sterna hirundo (Linnaeus, 1758), at the Densu floodplains, Accra', West African Journal of Applied Ecology 9, 141-148.

Amoani, K.Y., Appeaning Addo, K. \& Laryea, W.S., 2012, 'Short-term shoreline evolution trend assessment: A case study in Gleefe, Ghana', Jàmbá: Journal of Disaster Risk Studies 4(1), Art. \#45, 7 pages. http://dx.doi. org/10.4102/jamba.v4i1.45

Anokwa, Y., Martin, N. \& Muff, R., 2005, 'Coastal stability map of Greater Accra Metropolitan Area', Environmental and engineering geology map of Greater Accra Metropolitan Area, Accra, Ghana.

Appeaning Addo, K., Walkden, M. \& Mills, J.P., 2008, 'Detection, measurement and prediction of shoreline recession in Accra, Ghana', ISPRS Journal of Photogrammetry and Remote Sensing 63(5), 543-558. http://dx.doi. org/10.1016/j.isprsjprs.2008.04.001

Appeaning Addo, K., 2009, Detection, measurement and prediction of shoreline change in Accra, Ghana, Lambert Academic Publishing, Saarbrücken.

Appeaning Addo, K., Lloyd, L., Amisigo, B. \& Ofori-Danson, P.K., 2011, 'Impacts of coastal inundation due to climate change in a cluster of urban coastal communities in Ghana, West Africa', Remote Sensing 3(5), 2029-2050. http:// dx.doi.org/10.3390/rs3050962

Armah, A.K., Wiafe, G. \& Kpelle, D.G., 2005, 'Sea-level rise and coastal biodiversity in West Africa: A case study from Ghana', in P.S. Low (ed.), Climate Change and Africa, pp. 204-217, Cambridge University Press, Cambridge. http://dx.doi. Africa, pp. 204-217, Cambridge Uni
org/10.1017/CBO9780511535864.029

BirdLife International, 2012, Important bird areas factsheet: Densu Delta Ramsar site viewed 27 June 2012, from http://www.birdlife.org

Boko, M., Niang, I., Nyong, A., Vogel, C., Githeko, A., Medany, M. et al., 2007, 'Africa. Climate change 2007: Impacts, adaptation and vulnerability', in M.L. Parry, O.F. Canziani, J.P. Palutikof, P.J. van der Linden \& C.E. Hanson (eds.), contribution of Working Group II to the Fourth Assessment Report of the Intergovernmental Panel on Climate Change, pp. 433-467, Cambridge University Press, Cambridge.

Campbell, M.O., 2006, 'The sustainability of coconut palm, Cocos nucifera (Linnaeus, 1753), in coastal Ghana', Journal of Coastal Research 22(5), 1118-1124. http:// dx.doi.org/10.2112/04-0371.1 
Crooks, S., 2004, 'The effect of sea-level rise on coastal geomorphology', Ibis 146 (Suppl. 1), S18-S20. http://dx.doi.org/10.1111/j.1474-919X.2004.00323.x

Crowell, M., Leatherman, S.P. \& Douglas, B., 2005, 'Erosion: Historical analysis and forecasting', in M.L. Schwartz (ed.), Encyclopedia of Coastal Science, Encyclopedia of Earth Sciences Series, pp. 428-432, Springer, Dordrecht.

Dasgupta, S., Laplante, B., Meisner, C., Wheeler, D. \& Yan, J., 2007, 'The impact of sea-level rise on developing countries: A comparative analysis', World Bank Policy Research Working Paper 4136, 1(1), viewed 28 June 2012, from http://wwwwds. worldbank.org/servlet/WDSContentServer/WDSP/IB/2007/02/09/000016406_2 0070209161430/Rendered/PDF/wps4136.pdf

De-Graft, S.J., 2011, 'Environmental issues', radio broadcast, Joy FM, 08 April.

Dickson, M.E., Walkden, M.J. \& Hall, J.W., 2007, 'Systemic impacts of climate change on an eroding coastal region over the twenty-first century', Climatic Change 84(2), 141-166. http://dx.doi.org/10.1007/s10584-006-9200-9

EPA, 2003, Information for Africa climate technology transfer (IACTT), viewed 10 June 2012, from http://www.epa.gov.gh/iACTT/Ghana_VA\%20Coastal\%20Zone\%20. pdf

Fenster, M. \& Dolan, R., 1994, 'Large-scale reversals in shoreline trends along the US mid-Atlantic coast', Geology 22, 254-554.

Geoconsultants, 2005, 'Proposed bridge over River Densu on the Mallam-Kasoa road', Result of Test Borings (1), Accra, Ghana.

Ghana Survey Department, n.d., Map of Ghana, Map sales division of Ghana Survey Department, Accra.

Ibe, A.C. \& Quelennac, R.E., 1989, 'Methodology for assessment and control of coastal erosion in West Africa and Central Africa', UNEP Regional Sea Reports and Studies No. 107, United Nations Environment Programme, New York.

IPCC, 1995, 'The science of climate change', contribution of Working Group I to the Second Assessment Report of the Intergovernmental Panel on Climate Change, $\mathrm{p}$. 572, Cambridge University Press, Cambridge.

IPCC, 2007, 'Observations of climate change', in Core Writing Team, et al. (eds.), Climate change 2007: Synthesis report, contribution of Working Groups I, II, and III to the Fourth Assessment Report of the Intergovernmental Panel on Climate Change (IPCC), IPCC, Geneva.

Hinkel, J., Brown, S., Exner, L., Nicholls, R.J., Vafeidis, A.T. \& Kebede, A.S., 2011, 'Sealevel rise impacts on Africa and the effects of mitigation and adaptation: An application of DIVA', Regional Environmental Change, viewed 22 August 2011, from http://www.springerlink.com/content/v25561n65501/k3n/, http://dx.do org/10.1007/s10113-011-0249

Kebede, A.S., Nicholls, R.J., Hanson, S. \& Mokrech, M., 2012, 'Impacts of climate change and sea-level rise: A preliminary case study of Mombasa, Kenya', Journal of Coastal Research 28(1A), 8-19. http://dx.doi.org/10.2112/JCOASTRES-D-10-00069.1

Ly, C.K., 1980, 'The role of the Akosombo Dam on the Volta River in causing erosion in central and eastern Ghana (West Africa)', Marine. Geology 37, 323-332.

Mensah, J.V., 1997, 'Causes and effects of coastal sand mining in Ghana', Singapore Journal of Tropical Geography 18(1), 69-88. http://dx.doi.org/10.1111/14679493.00005
Muff, R. \& Efa, E., 2006, 'Ghana-Germany technical cooperation project: Environmental and engineering geology for urban planning in the Accra-Tema area', explanatory notes for the geological map for urban planning 1:50 000 of Greater Accra Metropolitan Area, Accra, Ghana.

Nicholls, R.J. \& Tol, R.S.J., 2006, 'Impacts and responses to sea-level rise: A global analysis of the SRES scenarios over the twenty-first century', Philosophical Transactions of the Royal Society A, 364(1841), 1073-1095.

Nicholls, R.J., Hanson, S., Herweijer, C., Patmore, N., Hallegatte, S., Corfee-Morlot, J. et al., 2007, 'Ranking port cities with high exposure and vulnerability to climate extremes - Exposure estimates', OECD environmental working paper no. 1 Organisation for Economic Co-operation and Development (OECD), Paris.

Oteng-Ababio, M., Owusu, K. \& Appeaning Addo, K., 2011, 'The vulnerable state of the Ghana coast: The case of Faana-Bortianor', Jàmbá: Journal of Disaster Risk Studies 3(2), 429-442.

Peehler, K., 2007, 'Nigeria in the dilemma of climate change', Country report, viewed 23 June 2012, from http://www.kas.de/proj/home/pub/33/2/dokument_id11468/index.htm

PSMSL, 2002, Obtaining sea level data, viewed 18 June 2012, from http://www.pol ac.uk/psmsl/datainfo/

Rahmstorf, S., Cazenave, A., Church, J.A., Hansen, J.E., Keeling, R.F., Parker, D.E. \& Somerville, R.C.J., 2007, 'Recent climate observations compared to projections', Science 316, 709, viewed 28 June 2012, from http://www.pik-potsdam. $\mathrm{de} / \sim$ stefan/Publications/Nature/rahmstorf_etal_science_2007.pdf. http://dx.doi. org/10.1126/science.1136843, PMid:17272686

Sagoe-Addy, K. \& Appeaning Addo, K., 2013, 'Effect of predicted sea level rise on tourism facilities along Ghana's Accra coast', Journal of Coastal Conservation and Management 17(1), 155-166. http://dx.doi.org/10.1007/s11852-012-0227-y

ScienceDaily, 2008, 'Stronger coastal winds due to climate change may have farreaching effects', viewed 07 August 2012, from http://www.sciencedaily.com/ releases/2008/12/081219172037.htm

SRI, 1966, 'Memoir no. 3: Soils of the Accra plains', State Publishing Corporation, Accra-Tema, Ghana.

Strauss, B.H., Ziemlinski, R., Weiss, J.L. \& Overpeck, J.T., 2012, 'Tidally-adjusted estimates of topographic vulnerability to sea level rise and flooding for the contiguous United States', Environmental Research Letters 7(1), 1-12. http:// dx.doi.org/10.1088/1748-9326/7/1/014033

Walkden, M.J.A. \& Hall, J.W., 2005, 'A predictive mesoscale model of the erosion and profile development of soft rock shores', Coastal Engineering 52(6), 535-563.

Wax, E., 2007, 'In flood-prone Bangladesh, a future that floats', The Washington Post.

Wellens-Mensah, J., Armah, A.K., Amlalo, D.S. \& Tetteh, K., 2002, 'Development and protection of coastal and marine environment in sub-Saharan Africa', Ghana National Report Phase 1: Integrated Problem Analysis, Global Environmental Facility (GEF) GEF MSP Sub-Saharan Africa Project (GF/6010-0016).

Woodroffe, C.D., 2003, Coasts: Form, process and evolution, Cambridge University Press, Cambridge.

World Bank, 1995, 'World Bank Africa: A framework for integrated coastal zone management, Environmental Sustainable Development Division and Land, Water and Habitat Division, Africa Region', World Bank, Washington DC 